\title{
THE INFLUENCE OF PERCEIVED ORGANIZATIONAL SUPPORT, JOB SATISFACTION AND ORGANIZATIONAL COMMITMENT TOWARD ORGANIZATIONAL CITIZENSHIP BEHAVIOR (A Study of the Permanent Lecturers at University of Lambung Mangkurat, Banjarmasin)
}

\author{
Meiske Claudia \\ Faculty of Economics and Business, Universitas Lambung Mangkurat, Indonesia \\ (meiske.claudia@gmail.com/mclaudia@unlam.ac.id)
}

\begin{abstract}
The population in this research is all of the permanent lecturers employed at University of Lambung Mangkurat (ULM). The respondents are taken from 4 academic ranks, which are represented by Asisten Ahli (Instructor), Lektor (Assistant Professor), Lektor Kepala (Associate Professor), and Guru Besar (Professor). One hundred and thirty samples were collected by using a proportional-stratified random sampling method. A Partial Least Square (PLS) method was used to analyze the data. The results showed that lecturers with a positive perception of the organizational support available to them feel more satisfied with their job, which in turn encourages the creation of a high organizational commitment and results in the emergence of positive organizational citizenship behavior (OCB). These study's results showed us the application of social exchange theory and organizational support theory in a higher educational institution. The findings of this study are considered to be important, as they provide additional empirical evidence regarding the importance of organizational support as a basis for improving the ULM lecturers' job satisfaction, organizational commitment and OCB. The implications and further research are also discussed.
\end{abstract}

Keywords: perceived organizational support, job satisfaction, organizational commitment, Organizational Citizenship Behavior (OCB).

JEL Classification: O15, M14, J28 


\section{INTRODUCTION}

Organizational citizenship behavior (OCB) plays a crucial role in improving the effectiveness, efficiency, and creativity of higher educational institutions. The emergence of OCB relies heavily on the willingness of the various parties involved to contribute positively, especially the lecturers as they are one important part of any higher educational institution. The discussion about OCB cannot be separated from the concept of the institutional organizational support provided to employees, as one of the factors that influence the formation of such behavior. To foster the lecturers' OCB or good extra-role behavior in higher educational institutions, adequate organizational support for each individual lecturer is needed. The perceived organizational support provided by a faculty's or university's management implies the extent to which the faculty's or university's management is considered to appreciate the value of the lecturers' contributions and how much they care about their welfare. In addition, to encourage every member of the organization to show good extra-role behavior, the attitudes associated with the work itself (work-related attitudes) should also be considered. Greenberg and Baron (2003) mentioned the attitudes related to work, which include job satisfaction and the employees' organizational commitment.

Kreitner and Kinicki (2003:274) state that organizational commitment reflects the state in which an individual identifies himself with the organization and the extent to which he/she is bound by its objectives. Employees who are committed to their organization and their work in general, have a tendency to believe that the work is central to their lives. They believe that work is a tribute. They also quickly take a stand against laziness. Employees who are committed to their organization or profession feel that the work they do satisfies their needs. Employees who have a commitment to their organization have a high level of involvement with its values and goals. In addition, when members of the organization feel well-treated and receive proper support from their organization, then they will feel satisfied and an obligation to reciprocate the organization's good treatment of them will exist. Their own job satisfaction and a sense of commitment to their organization will encourage them to undertake work beyond their formal role.

The impact of poorly perceived organizational support results in low satisfaction, which in turn causes a low degree of commitment to the organization. Ultimately, in these conditions, organizational citizenship behavior from each faculty member is much less likely to appear.

Research about OCB in state universities has been done by Ertürk (2005); Ngadiman, Eliyana, and Rahmawati (2013); and Yulianti (2015). Ertürk's research (2005) was conducted at a state college in Turkey, Ngadiman et al.'s research (2013) was conducted at Sebelas Maret University in Surakarta while Yulianti's research (2015) was conducted at state universities in Surabaya. Those previous studies and this study used different antecedents to induce OCB. The research of Ertürk (2005) used trust in the leadership as well as organizational justice as the antecedents, Ngadiman et al. (2013) used transformational leadership and the organizational climate as the antecedents, while Yulianti (2015) and this study used perceived organizational support (POS) as the antecedent of OCB. Ertürk's (2005), Ngadiman et al.'s (2013) and this study focused on OCB which relates to extra-role behavior, such as volunteering colleagues who have difficulty in attending class meeting/lecturing due to sickness or force major reasons, volunteering to perform additional tasks, obeying and being loyal to the organization, having and showing initiative and 
wanting to develop themselves to reflect good organizational behavior (good citizens). Yulianti's research (2015) focused more on OCB as an extra-role behavior that is useful for improving in-role performance. In addition OCB is considered to be a form of behavior that is not associated with obtaining rewards. Since the underlying theory used is the social exchange theory, then the OCB's antecedents should be based on the role of the organization in developing good relationships with its members. This study also used job satisfaction and organizational commitment as antecedent variables of OCB.

Furthermore, perceived organizational support (POS) can encourage the emergence of job satisfaction and organizational commitment. High levels of job satisfaction and organizational commitment from the organization's members (lecturers) will encourage the emergence of a positive OCB in the workplace.

There are some previous higher educational background studies that discuss some of the variables in this study, such as those conducted by Toker (2011); Mohammad, Habib, and Allias (2011), Noor (2009); Sambung (2012); Zeinabadi (2010); Beheshtifar, Nezhad, and Moghadam (2012); Rahman, Sulaiman, Nasir, and Omar (2014); Mousa and Alas (2016); Amos, Acquah, Antwi, and Adzifome (2015); and Ismail (2012). However, the results of these previous studies were inconclusive.

Based on the preliminary research conducted, there were some problems that arose, relating to the ULM lecturers' OCB. One of the problems indicates that the ULM lecturers' organizational compliance behavior to support ULM's re-accreditation is considered to be poor, as an online $\mathrm{CV}$ collection, requested by the rectorate, only produced completed CVs from $61 \%$ of the staff (data collected June 4, 2016). A pilot study of 30 lecturers resulted in $6.67 \%$ of the respondents rating their helpful behavior, organizational compliance behavior, individual initiative behavior, civic virtue behavior, and self development behavior in the 'fair' category. Another $13.33 \%$ of respondents indicated their sportsmanship behavior was in the 'good' category. Another $10 \%$ of respondents stated their organizational loyalty behavior was in the 'good' category. Based on the problem stated above, the research questions that arise are:

1. Does the perceived organizational support have a significant influence on the job satisfaction of the ULM lecturers?

2. Does the perceived organizational support have a significant influence on the organizational commitment of the ULM lecturers?

3. Does job satisfaction have a significant influence on the organizational commitment of the ULM lecturers?

4. Does job satisfaction have a significant influence on the organizational citizenship behavior of the ULM lecturers?

5. Does organizational commitment have a significant influence on the organizational citizenship behavior of the ULM lecturers?

6. Does the perceived organizational support have a significant influence on the organizational citizenship behavior of the ULM lecturers?

The target of this study was to obtain empirical evidence to explain the relationship between perceived organizational support and organizational citizenship behavior through the creation of job satisfaction and organizational commitment. The existence of empirical evidence will become the basis to provide certain recommendations to the leaders of the university and faculty, to guide them in formulating organizational policies relating to the organizational support provided to the lecturers, so they may increase the job satisfaction and organizational commitment, and 
encourage the emergence of positive organizational citizenship behavior among the lecturers, to improve their efficiency, effectiveness and organizational creativity.

The urgency of this study can be mentioned as follows: (1) Providing additional empirical evidence regarding the importance of organizational support as a basis for improving the lecturers' job satisfaction, organizational commitment and organizational citizenship behavior; (2) there have been no similar studies conducted at ULM with the same variables, so this research is expected to be feasible. Research on lecturers' OCB is important to do considering that currently ULM is working to improve the accreditation of its institutions. The role of lecturers as the spearhead of institutions through their organizational citizenship behavior (OCB) is needed to support various university programs and policies in order to achieve the highest accreditation in higher educational institutions. In addition, the occurrence of lecturers OCB assists the improvement of lecturers' performance as individuals, promote lecturers' performance as a group and ultimately improve the overall of institutional performance.

This research is expected to contribute to the theoretical aspects of management development, especially in the field of human resources management and organizational behavior in Indonesia, through an understanding of the importance of organizational support and its consequences in fostering positive organizational citizenship behavior (OCB) among lecturers in higher educational organizations, and it is expected to be able to explore new approaches with regard to all the aspects.

\section{LITERATURE REVIEW AND HYPOTHESES DEVELOPMENT}

This section describes the theories and concept used to develop the research model and hypotheses. The theories used in this study are the social exchange theory and the organizational support theory.

\section{Perceived Organizational Support}

Pack (2005) conceptualized perceived organizational support (POS) as an employee's perception regarding the extent to which his/her organization gives support to its employees, and the extent of the organization's readiness to provide assistance when needed. If the employees consider they receive a high level of organizational support, then the employees will absorb their membership of the organization into their identities, and then develop a relationship and a more positive perception about their organization. With this uniting of their membership in the organization with the employees' identity, the employees will feel part of the organization and feel a responsibility to contribute and perform their best for the organization. Referring to the norm of reciprocity, Gouldner (1960) argues that employees who feel a high level of organizational support are more likely to respond to their organizations with positive attitudes (such as higher affective commitment to the organizations) and demonstrate workplace behavior which is profitable (such as being more committed to helping to achieve the organization's goals and having a lower intention to quit).

In line with Pack's (2005) conceptualization of POS, Rhoades and Eisenberger (2002) explained POS as the employees' perceptions regarding the extent to which organizations value their contributions and care about their welfare.

\section{Job Satisfaction}

Wexley and Yukl (2005) stated that job satisfaction demonstrates the way an employee feels about his/her job. It deals with one's 
feelings toward one's work. Weiner, Graham, and Chandler (1982) stated job satisfaction as an attitude towards work-related conditions, facets, or aspects of the job. In line with Weiner et al.'s (1986) opinion, Vroom (cited in As'ad, 2003:104) noted job satisfaction as a reflection of a positive attitude. In a broad sense, Jernigan, Beggs, and Kohut (2002) reported job satisfaction as one's sense of satisfaction not only with the work, but also with the larger organizational context which the work exists in. Thus, we can conclude that job satisfaction related employee's satisfaction not only with work itself, but also with the broader organizational context related to the job.

\section{Organizational Commitment}

According to Aldag and Reschke (1997), organizational commitment is the strength of an individual's identification with, involvement in, and attachment to, the organization. Organizational commitment is related to the power of the individual to identify, engage and commit to the organization. The development of research into the construct of organizational commitment gave rise to various views, such as a consensus on organizational commitment in a multidimensional context. For example, Allen and Meyer (1990) introduced the construct of organizational commitment in three dimensions, namely: (1) Affective commitment, as an emotional attachment to organizations, where employees identify themselves with the organization and enjoy their membership of the organization; (2) continuance commitment, which is related to the costs occured when leaving the organization, and (3) normative commitment, which is the feeling of a responsibility to remain in the organization.

\section{Organizational Citizenship Behavior}

Organ, Podsakoff, and MacKenzie (2006:8) argued that organizational citizenship behavior served as the employees' extra-role behavior in a working group that causes them to do other tasks beyond the main tasks contained in their job description; which is a form of explicit action that is not recognized by the formal system of the company, but it can improve the overall efficiency and effectiveness of the organization. In line with this opinion, Coyle-Shapiro, Kessler, and Purcell (2004) stated organizational citizenship behavior as a type of extra-role behavior. Similar with the previous explanation, OCB according to Coyle-Shapiro et al. (2004) is considered to be the actions of employees who perform additional tasks in a working group that are not officially requested by the company but are the desire of the employees, and are undertaken voluntarily as a form of employee assistance to the organization.

According to Podsakoff, MacKenzie, Paine, and Bachrach (2000), OCB is a profound individual contribution which exceeds the demands of the person's role in the workplace, and has an impact on performance assessment. OCB includes the behavior of helping others, volunteering for extra duties, and adherence to the rules and procedures in the workplace. From an organizational point of view, OCB is necessary because the type of behavior included in OCB improves the resources' utilization and reduces the need for more formal control mechanisms, and does not require a lot of expense.

There are seven (7) types of extra-role behavior or organizational citizenship behavior exist, according to Organ et al. (2006: 297), namely: (1) helping behavior, (2) sportsmanship behavior, (3) organizational loyalty behavior, (4) organizational compliance behavior, (5) individual initiative behavior, (6) civic virtue behavior (sincerity), and (7) self-development behavior.

This section briefly describes the hypotheses formulation of this study, with the theoretical 
basis, or the general underlying concept, being taken from the previous empirical studies to strengthen the hypotheses formulation. Here is the elaboration of the hypotheses formulation in this study.

\section{Perceived Organizational Support and Job Satisfaction}

Pack (2005) stated perceived organizational support (POS) as an employee's perception regarding the extent to which the organization gives support to its employees, and the extent of the organization's readiness to provide assistance when needed. According to Rhoades and Eisenberger (2002), the perception of organizational support refers to the employees' perceptions regarding the extent to which the organizations assess their contributions and care about their welfare. In POS, there are elements of fairness, respect, attention to the lives of workers and consideration of the objectives and values of the employees (Eisenberger, Huntington, Hutchison, \& Sowa, 1986). The perception of organizational support is likely to increase if organizations implement a good reward system, provide opportunities for advancement and implement positive policies in the workplace. By considering job satisfaction as a form of an emotional response to a situation that reflects the work, performance assessment, or work experience, Locke (as cited in Brooke, Jr., Russell, \& Price, 1988) had a different argument that the perception of the organizational support the workers receive does have an effect on job satisfaction.

Several studies have found a positive relationship between POS and job satisfaction e.g. Liu (2004) and Wulani (2004); while a meta-analysis conducted by Riggle, Edmondson, and Hansen (2009) confirmed the findings related to POS with attitudinal outcomes. Similar results were also found in studies conducted by
Beheshtifar et al. (2012); Kuo, Su, and Chang (2015); and Kurtessis, Eisenberger, Ford, Buffardi, Stewart, and Adis (2015). Based on the above explanation, it is predicted that the lecturers who have a high perception of the support provided by the organization will tend to have high job satisfaction. In accordance with these predictions, the research hypothesis that can be formulated is:

$\mathrm{H}_{1}$ : Perceived organizational support significantly influences the ULM lecturers' job satisfaction.

\section{Perceived Organizational Support and Organizational Commitment}

The organizational support theory (OST) is used to describe the employees' emotional attachment to their organization. When employees feel that they are provided with good support from the organization, the employees feel responsible for replying this, in some manner, to their organization. The feeling of this obligation increases the employees' commitment to the organization (Eisenberger, Armeli, Rexwinkel, Lynch, \& Rhoades, 2001). In line with the organizational support theory, commitment can be identified as the impact of the employees' perceptions regarding the organizational support (Rhoades, Eisenberger \& Armeli, 2001). This relationship is proven through research conducted by Rhoades et al. (2001), using a sample of employees from various organizations. That study found that employees who felt that they have the support of their organization have a sense of meaningfulness in themselves. This increases the commitment of the employees. This commitment ultimately encourages the employees to help the organization achieve its goals and to improve their performance expectations, which are noticed and appreciated by the organization. 
The organizational support theory also assumes that perceived organizational support produces a feeling of obligation in the employees to help the organization achieve its goals, stay with the organization, and safeguard the welfare of the organization. Perceived organizational support has positive outcomes for both the employees and organizations. Perceived organizational support assumes that employees establish a common belief that an organization which concerned with the existence and wellbeing of its employees appreciates the contributions of the employees in the organization. Thus, employees feel that they must repay the organization for the benefits given to them by making profitable contributions to the organization.

Basically, lecturers who consider that organizational support is available at any time, if it is required and is enforced in a fair and reasonable way, are likely to have a good perception of the organizational support. The various experiences lecturers undergo during their relationship with their institution will affect their job satisfaction. The bigger and better that the organizational support given to them is, and the more aspects of their work that meet their expectations, then the lecturers' job satisfaction will be higher. Empirical studies that found a positive and significant relationship between perceived organizational support and job satisfaction were conducted by LaMastro (1999), Liu (2004), Wulani (2004), Liu (2009), Ekowati and Andini (2008), Riggle et al. (2009), Beheshtifar et al. (2012) as well as Kurtessis et al. (2015).

Based on the above explanation, it can be predicted that the higher the perceived organizational support is, the higher the lecturers' job satisfaction is. In accordance with these predictions, the research hypothesis that can be formulated is:
$\mathrm{H}_{2}$ : Perceived organizational support significantly influences the ULM lecturers' job satisfaction.

\section{Job Satisfaction and Organizational Commitment}

The relationship between job satisfaction and organizational commitment may occur when members of the organization have a high level of satisfaction within the organization, so that they have an attitude of belief and trust in, and a positive perception of, the organization. An employee's job satisfaction with various aspects of his/her work leads to the emergence of a strong commitment to the organization that hired $\mathrm{him} /$ her. Someone who feels satisfied in their work shows a positive attitude and behavior towards the organization. Workers who are satisfied demonstrate greater commitment compared with workers who are not satisfied. Satisfied workers have a greater commitment, which can be seen by their sense of ownership with the organization. They identify themselves as part of the organization and become increasingly tied to the organization; even more so when there is a match between their values and the organizational goals. This of course reinforces the workers' loyalty towards the organization. A closer attachment to the organization, a bigger sense of ownership and the more the organization's values match the worker's values are all indications of a person's affective commitment. It means a worker's perceived job satisfaction increases his/her affective commitment.

In addition, someone who is satisfied with their work is increasingly obliged to serve their organization. The organization has provided services and met the needs of its employees, so this raises a person's desire to provide feedback to the organization. Reciprocity may include the implementation of obligations, loyalty, and 
better performance. Satisfied workers demonstrate their commitment to the organization, not only based on their needs (continuance commitment), but also based on their sense of obligation (normative commitment) and their desire to achieve the organizational goals (affective commitment). If the normative and affective commitments increase due to the perceived satisfaction, then one no longer thinks of his/her needs, but more on his/her devotion to the organization.

Several previous studies conclude that job satisfaction is an antecedent to organizational commitment (Moorman, Niehoff, \& Organ, 1993; Lok \& Crawford, 2001; Lee, Nam, Park, \& Lee. 2006; Dickinson, 2009; Warsi, Fatima, \& Sahibzada, 2009; Zeinabadi, 2010; Ismail, 2012; Sambung, 2012; Ngadiman et al., 2013; and Amos et al., 2015). Based on the description above, it can be predicted that the higher a lecturer's job satisfaction in the various aspects of his/her work, the higher the lecturer's organizational commitment will be. In accordance with these predictions, a research hypothesis that can be formulated is:

$\mathrm{H}_{3}$ : Job satisfaction significantly influences the

ULM lecturers' organizational commitment.

\section{Job Satisfaction and Organizational Citizenship Behavior}

According to Organ et al. (2006), individuals who experience job satisfaction in an organization personally perform better. Robbins (2006) similarly states that a satisfied employee has a greater tendency to speak positively about the organization, help colleagues, and perform their work better than could normally be expected, as well as being more obedient to the call of duty.

There is a variety of evidence for a positive relationship between OCB and job satisfaction.
William and Anderson (1991) found a positive relationship between extrinsic and intrinsic job satisfaction for each dimension of OCB. Lee and Allen (2002) found that intrinsic job satisfaction is positively related to organizational level-OCB (OCB-O) but not with individual level-OCB (OCB-I). In the context of higher education in Malaysia, Ahmad (2006) found that 4 (four) work attitudes, namely: organizational commitment, job satisfaction, procedural fairness, and distributive justice, have a direct positive influence on academicians' organizational citizenship behavior.

Kuehn and Al Busaidi (2002), in their research, drew the conclusion that the most influential variables on OCB, compared with the other variables used in their study, were job satisfaction and normative commitment. This is supported by research conducted by Jahangir, Akbar, and Haq (2004), which found that employees with high job satisfaction also undertook their extra-role behavior better. This result supports the findings of the studies conducted by Bateman and Organ (1983), William and Anderson (1991), and Konovsky and Organ (1996).

Research conducted with the citizens of Oman found that there is a consistent positive relationship between job satisfaction and OCB in the Omani community. Other empirical studies that found a significant relationship between job satisfaction and OCB were conducted by Moorman et al. (1993), Moorman and Harland (2002), Wulani (2004), Lee et al. (2006), Nur and Organ (2006), as well as Zeinabadi (2010). In addition, Mohammad et al. (2011), Ngadiman et al., (2013) and Rahman et al. (2014) also found a significant relationship between job satisfaction and OCB in lecturers in the higher educational environment.

Based on the description above, it can be predicted that the higher a lecturer's job 
satisfaction for the various aspects of his/her work is, the higher the lecturer's organizational citizenship behavior will be. In accordance with the above predictions, a research hypothesis that can be formulated is:

$\mathrm{H}_{4}$ : Job satisfaction significantly influences the ULM lecturer's organizational citizenship behavior.

\section{Organizational Commitment and Organizational Citizenship Behavior}

The university needs to get the lecturers' organizational commitment, and this can be achieved by giving assistance and support to the lecturers to help them to conduct selfactualization and to achieve all their goals. The support can be given in the form of providing training for the lecturers to broaden their skills and help them solve problems in the workplace, ensure their work and give them the power to plan and inspect their work, as well as helping them to continuing their education and personal development. The support provided to help the lecturers' self-actualization contributes to building the lecturers' commitment and loyalty to the university, which has an impact on improving performance. In this case the lecturers who have a strong commitment towards the organization tend to show a positive OCB among their colleagues.

A number of empirical studies which describe the influence of the components of organizational commitment on OCB were conducted by Meyer and Allen (1991), who found that affective commitment has a relationship with OCB, while continuance commitment has no relationship with OCB. That research was supported by Morrison (1994) who stated that among the components of organizational commitment (affective, normative and continuant), the most dominant influence is affective commitment. Instead, Kuehn and $\mathrm{Al}$
Busaidi (2002), in their study, actually reached the conclusion that the most influential variables on OCB, compared with other variables used in the study, were job satisfaction and the normative commitment. In general it can be concluded that both affective, normative and continuance commitment obviously have an effect on the emergence of OCB.

Other empirical studies that prove the existence of a significant relationship between organizational commitment and OCB are by Lyn and Moorman (2002), Wulani (2004), Liu (2009), Lee et al. (2006), Nur and Organ (2006), Geh (2009), Noor (2009), Tan, Kuo, and Geh (2009), Zeinabadi (2010), Mohammad et al. (2011), Ngadiman et al., (2013), and Rageb, Abd-El-Salam, El-Samadicy, and Farid. (2013). Based on the description above, it can be predicted that the higher a lecturer's organizational commitment to his/her institution is, the higher the lecturer's organizational citizenship behavior will be. In accordance with the predictions, the following research hypothesis can be formulated is:

$\mathrm{H}_{5}$ : Organizational commitment significantly influences the ULM lecturer's organizational citizenship behavior.

\section{Perceived Organizational Support and Organizational Citizenship Behavior}

Perceived organizational support is defined as an employee's perception regarding the extent to which the organization he/she works for gives support to its employees, and the extent of the organization's readiness to provide assistance when needed (Pack, 2005). According to Rhoades and Eisenberger (2002), the perception of organizational support refers to the employees' perceptions regarding the extent their organization values their contributions and cares about their welfare. If the employees consider that a high level of organizational 
support exists then they are willing to incorporate their membership of the organization into their identities, and then develop a relationship and a more positive perception of the organization. The fusing of the employee's membership in the organization with the employee's identity makes the employee feel part of the organization, and that he/she has a responsibility to contribute and deliver his/her best performance for the organization. This allows for the emergence of the relationship between POS and OCB.

Shore and Wayne (1993) found that POS becomes a predictor of OCB and is positively related to performance and OCB. Workers who feel supported by their organization reciprocate this feeling, and thus lower the imbalance in the relationship by engaging in citizenship behavior. Miao and Kim (2010) and Chiang and Sheng (2011) also found a significant relationship between POS and OCB. Chiaburu, Chakrabarty, Wang and $\mathrm{Li}$ (2015) states that there is a significant positive relationship between POS and OCB, and the level of the relationship between these two variables depend on the particular cultural setting.

Based on the study of theoretical and empirical studies as described above, it can be predicted that the higher the perceived organizational support is, the higher the lecturer's organizational citizenship behavior will be. In accordance with the predictions, the research hypothesis that can be formulated is:

$\mathrm{H}_{6}$ : Perceived organizational support significantly influences the ULM lecturers' organizational citizenship behavior.

\section{RESEARCH METHOD}

This study is an explanatory (causality) study that aims to find explanations for the relationship between variables using hypothesis testing, the results of which can be used as a basis for generalizations (Sekaran, 2003:126). Primary data was collected using a survey questionnaire technique. The population in this study is all of the 1,022 ULM lecturers who have the status of civil servants, spread across 10 faculties. The sample size was 130 lecturers, selected through proportional-stratified random sampling.

Based on the pattern of causality in Figure 1, the various latent variables used in this study can be classified as follows: The independent variable (exogenous) is represented by perceived organizational support; the mediating variables (intervening) are represented by job satisfaction and organizational commitment; while the dependent variable (endogenous) is represented by organizational citizenship behavior. This study used survey methods with a questionnaire to collect the data. The questionnaire were made in a close-ended statement consists of 5 (five) points Likert scale.

\section{ANALYSIS AND DISCUSSION}

The respondents in this study consisted of the Chairman of the Program or Head of Department who were used as a separate sample to give an assessment of the OCB of the ULM lecturers as his/her subordinates. The lecturers selected as respondents are the source of the data as well as the subject of the study. The Chairmen of the Program or Heads of Department are used as data sources. They are the direct supervisors of the subjects studied, so they are formally authorized to provide an assessment of the lecturers who are their subordinates, and it is expected that this assessment would be more objective compared to the lecturers' selfassessment about their OCB. The unit of research analysis was done at the individual level. 


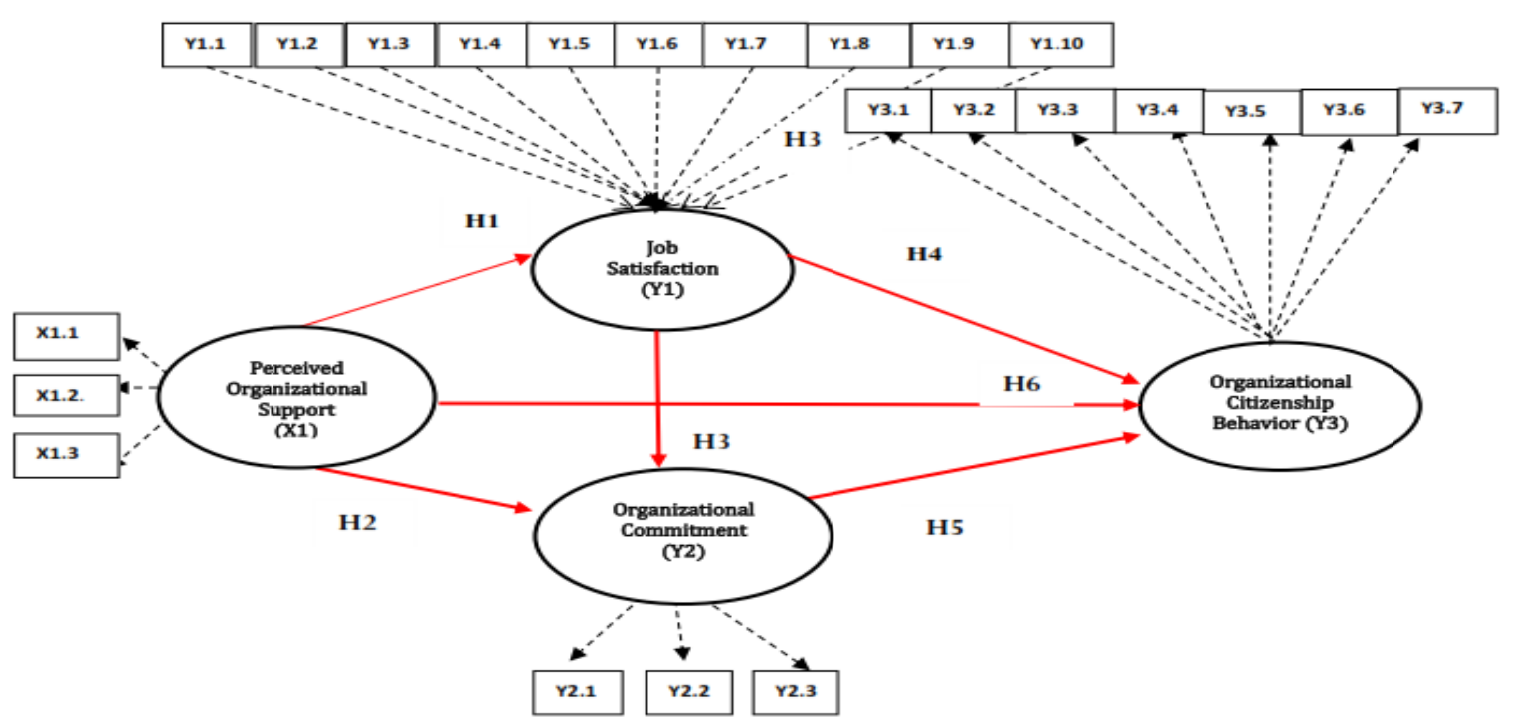

Not

Figure 1. Conceptual Model

es:

$\square$ : Latent Variable
$\square$ : Indicator (Manifest Variable)

X1 : Perceived Organizational Support

X1.1 Fairness

X1.2 Supervisory support

X1.3 Organizational rewards and job conditions

\section{Y1 : Job Satisfaction}

Y1.1 Satisfaction from achievement

Y1.2 Satisfaction from recognition

Y1.3 Satisfaction from work itself

Y1.4 Satisfaction from responsibility

Y1.5 Satisfaction from advancement

Y1.6 Satisfaction from company policy

Y1.7 Satisfaction from administration

Y1.8 Satisfaction from supervision

Y1.9 Satisfaction from interpersonal relations

Y1.10 Satisfaction from working conditions

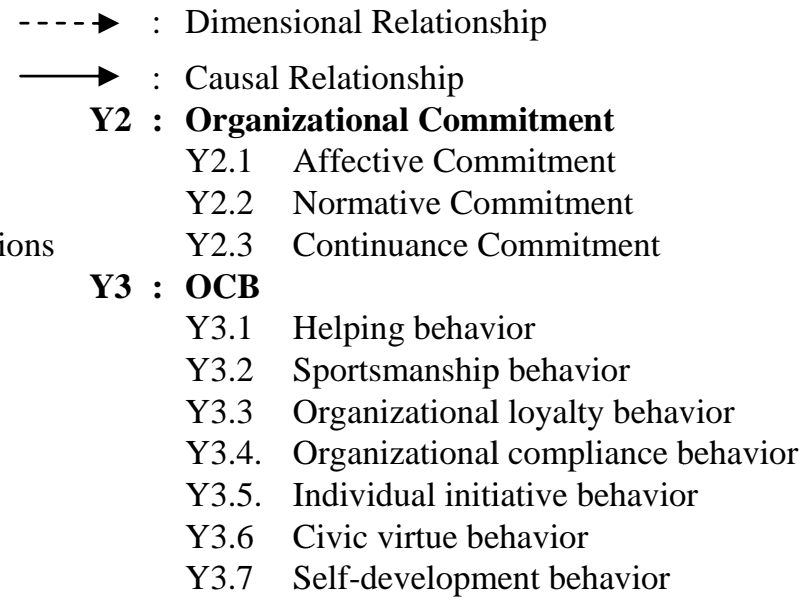

Y3.7 Self-development behavior
All of the 130 questionnaire were returned, giving a $100 \%$ response rate and all of them were fit for use in our analysis. Table 1 presents a description of the characteristics of this study samples. The description of the samples' characteristics provides an overview of the faculty of origin, gender, academic qualification, academic rank, and tenure. Based on this description, there is no missing value in the sample.

\section{Characteristics of Samples}

The representation of the survey's respondents, based on their faculty of origin, can be seen in Table 1, which shows that the majority of the sample came from the Faculty of Teacher Training and Education. Seventy-three out of the 130 respondents (56.15\%) are female, 105 out of the 130 respondent $(80.77 \%)$ have a master's (S2) degree, 51 out of the 130 respondent (39.23\%) hold the academic rank of Assistant Professor (Lektor) and 31 out of the 130 repondents $(23,84 \%)$ have a work tenure less than 10 years. 
Table 1. Characteristics of Sample

\begin{tabular}{|c|c|c|c|c|c|c|c|c|c|c|c|c|c|c|c|c|}
\hline \multirow[t]{2}{*}{ No } & \multirow[t]{2}{*}{ Faculty of origin } & \multirow{2}{*}{$\begin{array}{l}\text { Sample } \\
\text { Size }\end{array}$} & \multicolumn{2}{|c|}{ Gender } & \multicolumn{2}{|c|}{$\begin{array}{c}\text { Academic } \\
\text { Qualification } \\
\end{array}$} & \multicolumn{4}{|c|}{ Academic Rank } & \multicolumn{6}{|c|}{$\begin{array}{l}\text { Tenure } \\
\text { (years) }\end{array}$} \\
\hline & & & $\mathbf{M}$ & $\mathbf{F}$ & S2 & S3 & AA & $\mathbf{L}$ & LK & GB & $<5$ & $<\mathbf{1 0}$ & $<15$ & $<\mathbf{2 0}$ & $<25$ & $>25$ \\
\hline & $\begin{array}{l}\text { Teacher Training \& } \\
\text { Education }\end{array}$ & 25 & 13 & 12 & 20 & 5 & 5 & 9 & 11 & 1 & 6 & 3 & 0 & 0 & 9 & 7 \\
\hline 2. & Law & 7 & 5 & 2 & 7 & 0 & 1 & 2 & 4 & 0 & 1 & 2 & 1 & 0 & 2 & 1 \\
\hline 3. & Economics \& Business & 14 & 5 & 9 & 12 & 2 & 2 & 6 & 6 & 0 & 1 & 1 & 3 & 1 & 5 & 2 \\
\hline 4. & Political Science & 9 & 5 & 4 & 9 & 0 & 1 & 5 & 3 & 0 & 0 & 3 & 1 & 2 & 2 & 1 \\
\hline 5. & Agriculture & 14 & 7 & 7 & 6 & 8 & 1 & 4 & 7 & 2 & 0 & 3 & 2 & 0 & 7 & 2 \\
\hline 6. & Forestry & 9 & 6 & 3 & 3 & 6 & 0 & 3 & 5 & 1 & 0 & 0 & 4 & 3 & 2 & 0 \\
\hline 7. & Fishery \& Marine & 10 & 4 & 6 & 9 & 1 & 2 & 2 & 6 & 0 & 0 & 1 & 2 & 3 & 3 & 1 \\
\hline 8. & Technic & 15 & 8 & 7 & 13 & 2 & 6 & 5 & 4 & 0 & 3 & 6 & 2 & 3 & 1 & 0 \\
\hline 9. & Medicines & 15 & 1 & 14 & 15 & 0 & 6 & 6 & 3 & 0 & 0 & 7 & 6 & 2 & 0 & 0 \\
\hline \multirow[t]{2}{*}{10} & $\begin{array}{l}\text { Mathematics \& Natural } \\
\text { Science }\end{array}$ & 12 & 3 & 9 & 11 & 1 & 4 & 6 & 2 & 0 & 0 & 5 & 6 & 1 & 0 & 0 \\
\hline & TOTAL & 130 & 57 & 73 & 105 & 25 & 26 & 51 & 49 & 4 & 11 & 31 & 27 & 15 & 29 & 16 \\
\hline
\end{tabular}

Source: Data processed (2016)

Notes: $\mathrm{M}=$ Male; F= Female, $\mathrm{S} 2=$ Master's degree; $\mathrm{S} 3$ = Doctorate degree, $\mathrm{AA}=$ Asisten Ahli (Instructor), $\mathrm{L}=$ Lektor (Assistant Professor); LK=Lektor Kepala (Associate Professor); GB=Guru Besar (Professor)

The initial questionnaire was reviewed in advance by 5 senior lecturers from the organizational behavior course, to ensure its face and content validity. It also has been reviewed by the author's promoter and co-promoter, followed by a pilot test with 30 participants. Their comments and suggestions were used to improve the final version of the questionnaire.

Based on the outcome of the PLS measurement model in Table 2, the empirical model tested in this research has fulfilled the criteria of the validity and reliability tests. Job satisfaction's measurement is considered as a formative construct, by having ten (10) indicators, whereas the other constructs are considered as reflective constructs. The reason for considering job satisfaction as a formative construct is based on the understanding that someone's job satisfaction is the sum of the satisfaction he/she might experience from various aspects of his/her job. In this case, the indicators for the job satisfaction construct were drawn from Herzberg's motivation-hygiene theory. PLS provides the facility to test the formative construct. The validity test was conducted by examining $\mathrm{T}$ as bootstrap results in the outer weights' outcomes. The formative indicators are considered valid if the t-statistics values $>1.64$ (Hartono, 2011). The validity test for the formative construct has been done in accordance with the application of the PLS analysis procedure.

This study examines six main hypotheses. Hypothesis testing using the partial least square method were evaluated through the significance parameter of the t-statistics. Table 3 presents the results of the hypotheses testing using the partial least square techniques.

Based on the results of the hypotheses testing, it can be concluded that 3 of the 6 hypotheses were statistically significant. The results were able to explain the links among POS, job satisfaction, and organizational commitment as the antecedents of OCB. This study examined a conceptual model of the lecturers' OCB. The findings of this study are considered to be important, as they provide additional empirical evidence regarding the 
Table 2. Test results of PLS method of measurement model

\begin{tabular}{cccccc}
\hline & AVE $*$ & Composite Reliability* & R Square & Cronbach's Alpha** & Communality* \\
\hline X1 & 0.723942 & 0.886688 & - & 0.807189 & 0.723942 \\
Y1 & - & - & 0.619347 & - & 0.449345 \\
Y2 & 0.572551 & 0.800206 & 0.292613 & 0.625695 & 0.572551 \\
Y3 & 0.648804 & 0.927869 & 0.383400 & 0.909085 & 0.648805 \\
\hline
\end{tabular}

Source: Data processed (2016)

Note: * Valid if AVE and/or Communality > 0.5

** Reliable if Composite Reliability or Cronbach’s Alpha > 0.6

Table 3. Test results of PLS method of structural model

\begin{tabular}{lccccccc}
\hline & $\begin{array}{c}\text { Original } \\
\text { Sample (O) }\end{array}$ & $\begin{array}{c}\text { Sample } \\
\text { Mean (M) }\end{array}$ & $\begin{array}{c}\text { Standard } \\
\text { Deviation } \\
\text { (STDEV) }\end{array}$ & $\begin{array}{c}\text { Standard } \\
\text { Error } \\
\text { (STERR) }\end{array}$ & $\begin{array}{c}\text { t-statistics } \\
\text { (O/STERR) }\end{array}$ & p-value & Result \\
\hline $\mathbf{X 1}$-> Y1 & 0.78699 & 0.78801 & 0.04017 & 0.04017 & 19.59293 & 0.00000 & Supported \\
$\mathbf{X 1}$-> Y2 & 0.05368 & -0.00806 & 0.15752 & 0.15752 & 0.34077 & 0.73328 & Rejected \\
$\mathbf{X 1 ~ - > ~ Y 3 ~}$ & -0.07158 & -0.10627 & 0.13386 & 0.13386 & 0.53475 & 0.59282 & Rejected \\
$\mathbf{Y 1 ~ - > ~ Y 2 ~}$ & 0.49768 & 0.58641 & 0.16538 & 0.16538 & 3.00940 & 0.00262 & Supported \\
$\mathbf{Y 1 ~ - > ~ Y 3 ~}$ & 0.22841 & 0.29790 & 0.15791 & 0.15791 & 1.44643 & 0.14806 & Rejected \\
$\mathbf{Y 2 ~ - > ~ Y 3 ~}$ & 0.50872 & 0.48531 & 0.08369 & 0.08369 & 6.07894 & 0.00000 & Supported \\
\hline
\end{tabular}

Source: Data processed (2016)

importance of organizational support as a basis for improving the ULM lecturers' job satisfaction, organizational commitment and OCB. The following section is intended to discuss the results of this study in detail.

Hypothesis 1 states that POS influences job satisfaction. This hypothesis was statistically supported by the study's findings. This is consistent with the opinion of Rhoades and Eisenberger (2002) who stated that job satisfaction is directly influenced by the employees' perception of the organization. Employees who have a positive perception of the organizational support available to them feel more satisfied in their work. POS contributes to the overall job satisfaction through the socioemotional needs of the lecturers, raising their expectations of performance-rewards, and indicating the availability of assistance when needed. The results also support the idea of
Baron and Greenberg (1990), which identified factors that cause job satisfaction, such as the organizational factors, company-specific policies and perceptions about the quality of supervision (perceived quality supervision). These three factors exist in the dimensions of POS found at ULM.

The results of this study are also consistent with the previous research of Chiang and Sheng (2011), Rhoades and Eisenberger (2002), Liu (2004), Wulani (2004), Liu (2009), Ekowati and Andini (2008), Riggle et al. (2009), Beheshtifar et al. (2012), Kuo et al., (2015) and Kurtessis et al. (2015) which found a positive relationship between POS and job satisfaction, which means if the POS increases, job satisfaction increases, and vice versa. The POS variable in this study was measured by three indicators, namely fairness, supervisory support, and organizational rewards and working conditions. Of the three 
indicators used as a reflection of the POS, the average value of the highest response was for the dimension of fairness (3.71), followed by supervisory support (3.29) and organizational rewards and working conditions (3.21). The higher response to the dimension of fairness indicates that the ULM lecturers prioritize how any element of fairness is applied in the implementation of policies made by the faculty and the university.

Hypothesis 2 states that perceived organizational support influences organizational commitment. This study found that the ULM lecturers' perceived organizational support did not positively influence their organizational commitment. It means that Hypothesis 2 was not statistically supported. This finding is not consistent with the opinion of Eisenberger et al., (1986), who stated that the perceived organizational support affects the level of organizational commitment. The results of this study are not consistent with some of the studies that found a significant correlation between the POS with affective commitment, such as studies by Shore and Tetrick (1991); Shore and Wayne (1993); Wayne, Shore, and Liden (1997); and Randall, Cropanzano, Borman, and Birjulin (1999), and the results are also not consistent with a finding of Wayne et al. (1997) which states that there is a positive correlation for POS with normative commitment. Supposedly, when organizations make investments and give recognition to their workers, they boost the social exchange relationship (Wayne et al., 1997). Furthermore, the results of this study are not consistent with the findings of Liu (2004) who claimed that a high POS will result in low turn-over intentions, the emergence of a desire to support the organization with better performance, an increased organizational commitment and OCB. The study is not consistent with the research of Lew (2009) who discovered the role of POS in the sense of responsibility, affective commitment and the low turn-over of teachers at private colleges in Malaysia. Furthermore, the results of this study do not support the findings of Chiang and Sheng (2011), Eisenberger et al. (2001), Liu (2004), Wulani (2004), Liu (2009), Ekowati and Andini (2008), Riggle et al. (2009), Beheshtifar et al. (2012) as well as Kurtessis et al. (2015).

The inconsistency of this study's findings, compared to previous empirical research, is due to the organizational support provided by the university to the lecturers, which is still considered to be minimal. Related to RI Law No.14/2005 on Teachers and Lecturers and Government Regulation 37/2009, which states that lecturers, as professional educators and scientists, should be provided with the maximum possible support by their universities' leadership to allow for the implementation of the lecturers' tasks, such as to transform, develop and disseminate science and technology and the arts through education, research and community service. Besides, this institutional support for the lecturers can be administered in the form of procurements and increased academic activities, as an additional source of income, or as increased expertise and proficiency/skills that meet the quality standards of the profession, an improvement in their academic qualifications, as well as increased competence and responsibility for their tasks' execution as professional lecturers. In addition, the organizational support from the leaders of the universities should be a guarantee of the fulfillment of the right of lecturers to earn an income above that required for the minimum necessities of life, and should include health insurance; promotions and awards; protection of intellectual property; the chance to improve their competences; academic freedom, an academic forum and scientific autonomy, freedom in giving students' graduation ratings and the freedom to join professional 
associations. On the other hand, the lecturers have their responsibility to implement Tridharma Perguruan Tinggi; which is to plan, implement and evaluate the teaching and learning process; to promote and develop academic qualifications; act objectively and not discriminate in any way; upholding the legislation, codes of ethics, religious values and ethics; as well as preserving the unity and integrity of the nation. The results of this study explain that the relationship between POS and organizational commitment should be done through the mechanism of job satisfaction. That is, the effect of POS on the lecturers' organizational commitment can only occur through the role of job satisfaction.

Hypothesis 3 states that job satisfaction influences organizational commitment. This hypothesis was statistically supported by the study's findings. This finding is consistent with the studies of Moorman et al. (1993), Lok and Crawford (2001), Lee et al. (2006), Dickinson (2009), Warsi et al. (2009), Zeinabadi (2010), Ismail (2011), Sambung (2012), Ngadiman et al. (2013), and Amos et al. (2015) which all showed that job satisfaction is an antecedent to organizational commitment. The relationship between job satisfaction and organizational commitment can occur when members of the organization have a high level of satisfaction within the organization, so that they have the attitude, confidence, trust and a positive perception of the organization that hired them. The employees' satisfaction with the various aspects of their work led to the emergence of a strong commitment to the organization that employs them.

The results of this study are also consistent with the study of Pounder and Reyes (1993) in LaMastro (1999) which states that the level of commitment of teachers is directly proportional to the satisfaction they feel at work. Related to this result, a lecturer who is satisfied in his work shows a positive attitude and behavior towards the organization. Satisfied lecturers demonstrate greater commitment compared to those who are dissatisfied. Satisfied lecturers' commitment can be seen from their higher sense of belonging to the organization. They identify themselves as part of the organization and feel increasingly tied to the organization; even more so when there is a match between their values and the goals of the organization where they work. This of course reinforces the lecturers' loyalty towards the organization. A closer attachment to the organization, a higher sense of belonging and a closer match between the organization's values and the lecturers' values are indications of increased lecturers' affective commitment. Thus, the perceived job satisfaction increases the lecturers' affective commitment.

Additionally, a lecturer who is satisfies at his work feels a greater obligation to serve the organization. The organization has been providing services and meeting the needs of the lecturer, allowing him/her to feel satisfied and happy. This raises a person's desire to reciprocate in some manner to the organization. This may include the implementation of obligations, loyalty, and better performance. If the increase in the obligation to serve the organization is caused by the satisfaction felt by the lecturer, then meaningful job satisfaction increases his/her normative commitment. Lecturers are completely satisfied not only to work to meet their needs; but will also show their loyalty, sacrifice and dedication, and feel increasingly obliged to defend the values and goals of the organization, as well as trying to improve their own performance. This shows that job satisfaction is directly proportional to the affective and normative commitment. The greater the job satisfaction of the lecturers, the higher the affective and normative commitment 
will be. Satisfied lecturers demonstrate their commitment to the organization, not only based solely on their needs (continuance commitment) but also based on their obligation (normative commitment) and the desire to achieve the goals of the organization (affective commitment).

Hypothesis 4 states that job satisfaction influences organizational citizenship behavior. This study found that the ULM lecturers' job satisfaction did not positively influence their organizational citizenship behavior. It means that Hypothesis 4 was not statistically supported. This finding is not consistent with the study of William and Anderson (1991) who found a positive relationship between extrinsic and intrinsic job satisfaction for each dimension of OCB. In addition this study did not support the results of Ahmad (2006) which states that the four (4) working attitudes: organizational commitment, job satisfaction, procedural fairness, and distributive justice all have a direct positive influence on lecturers'/ academicians' organizational citizenship behavior. Furthermore, the result of this study is not consistent with Othman (2002), who found that job satisfaction, organizational commitment and ethical climate has a relationship with OCB.

The results of this study are also not consistent with the findings of Moorman et al. (1993), Moorman and Harland (2002), Wulani (2004), Lee et al. (2006), Nur and Organ (2006), Zeinabadi (2010), Muhammad et al. (2011), Ngadiman et al., (2013), Rahman et al. (2014) and Sambung (2012), who all found a significant relationship between job satisfaction and organization level-OCB (OCB-O ) in higher educational environments. The results of this study explain that there is no direct relationship between job satisfaction and OCB but the relationship may occur through the role of organizational commitment. It is found that high job satisfaction cannot automatically lead to good OCB, but should be done through the creation mechanisms of organizational commitment that led to the emergence of positive OCB.

Hypothesis 5 states that the lecturers' organizational commitment influences their OCB. This hypothesis was statistically supported by the study's findings. This is consistent with the study of Meyer, Allen, and Smith (1993) which states that organizational commitment has a positive correlation with the type of behavior called OCB. Organizational commitment is basically seen as the engagement and loyalty displayed by an employee to his employer. Such loyalty, associated with the context of this research, implies that a lecturer with high organizational commitment is certainly willing to do more than just his/her formal tasks. A lecturer with high organizational commitment will demonstrate behavior that exceeds his/her in-role (extra-role/OCB).

The results of this study showed similarities with the findings of other studies that assess the role of the components of organizational commitment which have a dominant influence on OCB. Research conducted by Meyer and Allen (1991) concluded that the shape of affective organizational commitment has a very close relationship with OCB, while continuance commitment is not related to OCB. The results of this study also have similarities with the research findings of Morrison (1994), which state that affective commitment is the dominant influence on OCB. Based on the responses obtained from the respondents in this study, it is known that they gave their highest response to affective commitment, followed by normative commitment and continuance commitment.

The results of this study are not consistent with the results of Kuehn and Al Busaidi (2002), who concluded that the variable with the most influence on job satisfaction and OCB is normative commitment. In general, the results of 
this study provide support to some previous empirical studies that found the existence of a significant relationship between organizational commitment and OCB, such as those by Moorman and Harland (2002), Wulani (2004), Liu (2009), Lee et al. (2006), Nur and Organ 2006), Geh (2009), Noor (2009), Tan et al. (2009), Zeinabadi (2010), Mohammad et al. . (2011) and Ngadiman et al. (2013).

Hypothesis 6 states that perceived organizational support influences organizational citizenship behavior. This study found that the ULM lecturers' perceived organizational support did not positively influence their organizational citizenship behavior. It means that Hypothesis 6 was not statistically supported.

This finding is not consistent with the study of Shore and Wayne (1993) which found that the POS becomes a predictor of OCB, and is positively related to performance and OCB. Furthermore, the results of this study are not consistent with Liu (2009), Miao and Kim (2010), Chiang and Sheng (2011), Yulianti (2015), and Chiaburu et al. (2015), who all found a significant relationship between POS and OCB. The results of this study explain that the relationship between POS and OCB must be formed through the creation mechanism of job satisfaction and organizational commitment.

\section{CONCLUSION}

The results of this study explain that the ULM lecturers' POS contributes significantly to establishing or improving their job satisfaction. The lecturers' high perception of the fairness of the support provided to them, and the rewards for good performance given by the university, as well as their comfortable working conditions proved to contribute significantly to their job satisfaction.
The ULM lecturers' job satisfaction was proved to significantly influence their organizational commitment. It can be explained that the lecturers' satisfaction with various aspects of their work formed their general job satisfaction, which in turn encouraged the creation of a high commitment to their organization.

The ULM lecturers' organizational commitment was proved to significantly influence their OCB. The results of this study explain that the lecturers' organizational commitment makes an important and significant contribution to the formation of their OCB. The lecturers' organizational commitment was measured on the basis of the indicators of affective, normative and continuance commitment, and proved to influence the existence of their OCB.

These findings can be used as a source of information for policy makers at ULM Banjarmasin, regarding their efforts to improve their lecturers' OCB through the improvement of the lecturers' perceived organizational support, job satisfaction and organizational commitment. Based on these findings, improvements to the existing policies that have been implemented relating to the lecturers' interests and rights can be conducted.

The results of this study indicate that POS indirectly influences OCB lecturer through job satisfaction and organizational commitment. Although OCB is the behavior of lecturers which does not expect any rewards but the results of this study indicate that high POS affects lecturer satisfaction, establishes lecturers' organizational commitment and encourages the emergence of OCB. This indicates that the high awareness and support of the institution to the lecturer in the implementation of three pillars of higher education (comprising education, research and community service - Tridharma Perguruan Tinggi) will affect the creation of lecturer's 
satisfaction and form a high organizational commitment to the institution so as to encourage the lecturer to show the positive extra-role behavior in the form OCB. This indirectly indicates the existence of a social exchange mechanism from the management side of the institution as superiors with the lecturers as subordinates. Existing evidence also indicates the enactment of reciprocal norms in organizational support theory which explain lecturers who feel cared for, supported and facilitated by the agency will reciprocate the good for the institution by showing positive behavior in the form of OCB.

The result of PLS output shows that the relationship between POS and OCB is not significant with negative direction. This indicates two things: firstly, for some lecturers it may be true that a high POS will cause their OCBs to be low because high institutional support in the implementation of three pillars of higher education (comprising education, research and community service - Tridharma Perguruan Tinggi) will encourage them to pursue personal achievement that leads to their lack of time and opportunity to show OCB at work. Secondly, for some lecturers it may be true that low POS will still encourage them to show high OCB because essentially lecturer is a profession full of dedication. The consequence of this is that no matter how much support the institute provides in perform their duties, the lecturers will still perform their best not only in their in-role behavior but also in their extra-role behavior (OCB).

\section{RECOMMENDATION}

Based on the results and conclusions obtained in this study, the following suggestions are proposed:

To improve the POS, the organization may implement a fair system of reward (and punishment), provide fair and equal support to all the lecturers in fulfilling their job responsibilities and rights, provide equitable and fair career advancement opportunities, and enact positive policies in the workplace as well creating good working conditions.

To increase lecturers' job satisfaction, the university administrator needs to pay attention to items or indicators that score poorly in awards given by the leadership, the organization and management of employment practises, the policies that exist covering employment, promotion at work, as well as providing clear career paths at work. The faculty and the university administrator must find ways to recognize lecturers contributions by giving annual awards and pursue more transparently cultural communications, which in particular can improve the consensus among the lecturers in prioritizing their contribution to education, teaching and research. Understanding the underlying factors of the lecturers' job satisfaction can direct the administrator to develop more workable initiatives to improve the lecturers' morale and commitment.

The lecturers' organizational commitment can be improved by holding job evaluations about the lecturers' willingness to work optimally. Job evaluations can be used to find flaws with the lecturers' methods, so as to provide guidance and insight to the lecturers in order to maximize their skills, knowledge and improve their ability to perform better. Furthermore, the faculty officials should be able to encourage the lecturers to actively participate in the decision-making process and transform the lecturers' demands into concrete actions to gain all of the academic community's recognition.

The effort to improve the OCB of the lecturers should be considered internal and external factors. The internal factors come from 
within the faculty, such as the lecturers' morals, their satisfaction with their job and organization, their desire and positive attitude toward the work and organization; while the external factors include improvements to the management system, the leadership system and the organizational culture.

Further research is recommended to investigate other variables that may influence OCB, such as organizational performance and effectiveness. It is also recommended that moderator and mediator variables such as age, gender, length of work and so forth are included into the existing models, or that some new variables, as OCB's antecedents, such as personality, work climate and organizational culture, are incorporated.

\section{REFERENCES}

Ahmad, Z. (2006). Job attitudes as a determinant of organizational citizenship behaviors: A study among academic staffs in Kuching polytechnic, Sarawak (Doctoral dissertation, Faculty of Business Management, Universiti Utara Malaysia).

Aldag, R., \& Reschke, W. (1997). Employee value added: Measuring discretionary effort and its value to the organization. Center for Organization Effectiveness, 1-8.

Allen, N. J. \& Meyer, J. P. (1990). The measurement and antecedent of affective, continuance and normative commitment to the organization. Journal of Occupational Psychology, 63(1), 1-18.

Amos, P. M., Acquah, S., Antwi, T., \& Adzifome, N. S. (2015). A comparative study of factors influencing male and female lecturers' job satisfaction in Ghanaian higher education. Journal of Education and Practice, 6(4), 1-10.

As'ad, M. (2003). Psikologi industri: Seri sumber daya manusia [Psychology of industry: Human resource serial]. Liberty. Yogyakarta.
Baron, R.A. \& Greenberg J. (1990). Behavior in organization: Understanding and managing the human side of work (Third Edition). Toronto: Allyn and Bacon.

Bateman, T. S. \& Organ, D.W. (1983). Job satisfaction and the good soldier: The relationship between affect and employee citizenship. Academy of Management Journal, 26(4), 587-595.

Brooke, P.P., Jr., D.W. Russell, and J.L. Price. (1988). Discriminate validation of measures of job satisfaction, job involvement, and organizational commitment. Journal of Applied Psychology, 73(2). 139 - 145.

Greenberg, J. and Baron, R.A. (2003). Behavior in organizations: Understanding and managing the human side of work $\left(18^{\text {th }}\right.$ Edition). Prentice-Hall, Upper Saddle River.

Beheshtifar, M., H. A. Nezhad and M.N. Moghadam. (2012). Investigation of perceived organizational support on employees' positive attitudes toward work. Interdisciplinary Journal of Contemporary Research in Business, 4(8), 432-442.

Chiaburu, D.S., Chakrabarty, S., Wang, J., and Li, N. (2015). Organizational support and citizenship behavior: A comparative crosscultural meta-analysis. Management International Review, 55(5), 707-736.

Chiang, C. F., \& Hsieh, T. S. (2012). The impacts of perceived organizational support and psychological empowerment on job performance: The mediating effects of organizational citizenship behavior. International journal of hospitality management, 31(1), 180-190.

Dickinson, L. (2009). An examination of the factor affecting organizational citizenship behavior. (Honor Thesis, Accounting Department, The University of Tennessee).

Eisenberger, R., Huntington, R., Hutchison, S., \& Sowa, D. (1986). Perceived organizational support. Journal of Applied Psychology, 71(3), 500-507.

Eisenberger, R., Armeli, S., Rexwinkel, B., Lynch, P. D., \& Rhoades, L. (2001). Reciprocation of perceived organizational 
support. Journal of Applied Psychology, 86(1), 42-51.

Ekowati, D., \& Andini, M. (2008). Perceived organizational support (POS) and organizational commitment. Jurnal Manajemen Teori dan Terapan [Journal of Theory and Applied Management], 1(2).

Ertürk, A. (2005). Increasing organizational citizenship behavior of Turkish academician: Mediating role of trust in supervisor on the relationship between organizational justice and citizenship behavior. Journal of Managerial Psychology, 22(3), 257-270.

Geh, Z.Y.E. (2009). A study of the effects of mediators between spirituality at work and organizational citizenship behavior. (Master's thesis). Singapore Management University.

Gouldner, A. W. (1960). The norm of reciprocity: A preliminary statement. American Sociological Review, 161-178.

Ismail, N. (2012). Organizational commitment and job satisfaction among staff of higher learning education institutions in Kelantan (Doctoral dissertation, Universiti Utara Malaysia).

Coyle-Shapiro, J. A. M., Kessler, I., \& Purcell, J. (2004). Exploring organizationally directed citizenship behaviour: reciprocity or 'it's my job'?. Journal of Management Studies, 41(1), 85-106.

Jahangir, N., Akbar, M. M., \& Haq, M. (2004). Organizational citizenship behavior: Its nature and antecedents. BRAC University Journal, 1(2), 75-85.

Jernigan, I. E., Beggs, J. M., \& Kohut, G. F. (2002). Dimensions of work satisfaction as predictors of commitment type. Journal of Managerial Psychology, 17(7), 564-579.

Hartono, M.J. (2011). Konsep dan aplikasi structural equation modeling berbasis varian dalam penelitian bisnis. [Concept and application of varian-based structural equation modeling]. UPP STIM YKPN. Jogjakarta.
Konovsky, M.A. \& Organ, D.W. (1996). Dispositional and contextual determinants of organizational citizenship behavior. Journal of Organizational Behavior, 17 (3), 253-266.

Kreitner, R. and A. Kinicki. (2003). Perilaku organisasi (Edisi Pertama). [Organizational behavior ( $1^{\text {st }}$ Edition)], Terjemahan: Erly Suandy. Penerbit Salemba Empat, Jakarta.

Kuehn, K.W. \& Al-Busaidi, Y. 2002. Citizenship behavior in a non-western context: An examination of the role of satisfaction, commitment and job characteristics on self-reported OCB, International Journal of Commerce \& Management, 12(2), 107-125.

Kuo, Y. K., Su, Y. Y., \& Chang, B. L. (2015). The study on relationships of perceived organizational support and job satisfaction in taiwan hospitality service industry. Managing Intellectual Capital and Innovation for Sustainable and Inclusive Society. Proceedings of the MakeLearn and Management, Knowledge and Learning Joint International 2015 (pp. 1977- 1980). Bari, Italy.

Kurtessis, J.M., Eisenberger R., Ford, M.T., Buffardi, L.C., Stewart, L.C., \& Adis, C.S. (2015). Perceived organizational support: A meta-analytic evaluation of organizational support theory. Journal of Management, 43(6), 1854-1884.

LaMastro, V. (1999). Commitment and perceived organizational support. National Forum of Applied Educational Research Journal, 12 (3).

Lee, Y.K., Nam, J. H., Park, D. H., \& Lee, K. A. (2006). What factors influence customer oriented prosocial behavior of customer contact employees? Journal of Service Marketing, 20(4), 251-264.

Lew, T. (2009). The relationships between perceived organizational support, felt obligation, affective organizational commitment and turnover intention of academics working with private higher educational 
institutions in Malaysia. European Journal of Social Sciences, 9(1), 72-87.

Liu, W. (2004). Perceived organizational support: Linking human resource management practices with important work outcomes. (Doctoral Dissertation. University of Maryland. College Park).

Liu, Y. (2009). Perceived organizational support and expatriate organizational citizenship behavior: The mediating role of affective commitment towards the parent company. Personnel Review, 38(3), 307-319.

Lok, P. \& Crawford, J. (2001). Antecedents of organizational commitment and the mediating role of job satisfaction. Journal of Managerial Psychology, 16(8), 594-613.

Meyer, J. P., \& Allen, N. J. (1991). A threecomponent conceptualization of organizational commitment. Human Resource Management review, 1(1), 61-89.

Meyer, J. P., Allen, N. J., and Smith, C. A. (1993). Commitment to organizations and occupations: Extension and test of a threecomponent conceptualization. Journal of Applied Psychology, 78 (4), 538-551.

Miao, R. \& Kim, H.G. (2010). Perceived organizational support, job satisfaction and employee performance: A chinese empirical study. Journal of Service Science and Management, 3, 257-264.

Mohammad, J., Habib, F.Q., \& Allias, M.A. (2011). Job satisfaction and organizational citizenship behavior: An empirical study at higher learning institutions. Asian Academy of Management Journal 16(2), 149-165.

Moorman, R.H., Niehoff, B.P., \& Organ, D.W. (1993). Treating employees fairly and OCB: Sorting the effects of job satisfaction, organizational commitment and procedural justice. Employees Responsibilities and Rights Journal, 6(3), 209-225.

Moorman, R. H., \& Harland, L. K. (2002). Temporary employees as good citizens: Factors influencing their OCB performance. Journal of Business and Psychology, 17(2), 171-187.
Morrison, E.W. (1994). Role definitions and organizational citizenship behavior: The importance of the employee's perspective. Academy of Management Journal 37(6), 1543-1567.

Mousa, M., \& Alas, R. (2016). Workplace spirituality and organizational commitment: A study on the public schools teachers in Menoufia (Egypt). African Journal of Business Management, 10(10), 247.

Ngadiman, A. Eliyana, \& D. Ratmawati. (2013). Influence of transformational leadership and organization climate to the work satisfaction, organizational commitment and organizational citizenship behavior on the educational personnel of Sebelas Maret University, Surakarta. Educational Research International, 1(1).

Noor, A. (2009). Examining OCBS as the outcome of organizational commitment: A study of universities teachers of Pakistan. Proceedings $2^{\text {nd }} C B R C$. Lahore, Pakistan. November 14.

Organ, D. W., Podsakoff, P. M., \& MacKenzie, S. B. (2006). Organizational citizenship behavior: Its nature, antecedents, and consequences. Thousand Oaks, CA: Sage Publications, Inc.

Pack, S.M. (2005). Antecedents and consequences of perceived organizational support for NCAA athletic administrators. (Doctoral dissertation, The Ohio State University)

Podsakoff, P. M., MacKenzie, S. B., Paine, J. B., \& Bachrach, D. G. (2000). Organizational citizenship behaviors: A critical review of the theoretical and empirical literature and suggestions for future research. Journal of Management, 26(3), 513-563.

Peraturan Pemerintah Nomor 37 Tahun 2009 tentang dosen. [Government regulation Number 37, 2009 on lecturers.]

Rageb, M. A., Abd-El-Salam, E. M., ElSamadicy, A., \& Farid, S. (2013). Organizational commitment, job satisfaction and job performance as a mediator between role stressors and turnover intentions a study from an Egyptian cultural perspective. Inter- 
national Journal of Business and Economic Development (IJBED), 1(1), 34-54.

Rahman, U., Sulaiman, W.S.W., Nasir, R., and Omar, F. (2014). The role of job satisfaction as mediator in the relationship between selfefficacy and organizational citizenship behavior among Indonesian teachers. International Journal of Business and Social, 5(9).

Randall, M. L., Cropanzano, R., Bormann, C. A., \& Birjulin, A. (1999). Organizational politics and organizational support as predictors of work attitudes, job performance, and organizational citizenship behavior. Journal of Organizational Behavior, 20(2), 159-174.

Rhoades, L., R. Eisenberger, \& S. Armeli. (2001). Affective commitment to the organization: the contribution of perceived organizational support. Journal of Applied Psychology, 86, 825-836.

Rhoades, L., \& Eisenberger, R. (2002). Perceived organizational support: a review of the literature. Journal of Applied Psychology, 87, 698-714.

Riggle, R. J., Edmondson, D. R., \& Hansen, J. D. (2009). A meta-analysis of the relationship between perceived organizational support and job outcomes: 20 years of research. Journal of Business Research, 62(10), 1027-1030.

Robbins, S.P. (2006). Perilaku organisasi (Edisi Kesepuluh). [Organizational behavior $\left(10^{\text {th }}\right.$ Edition)]. Translated by: Benyamin Molan. Indeks. Jakarta.

Sambung, R. (2012). Pengaruh kepuasan kerja, komitmen organisasional, kepribadian and profesionalisme dosen terhadap OCBS serta dampaknya terhadap kinerja dosen (Studi pada Universitas Palangka Raya). [The influence of job satisfaction, organizational commitment, personality and lecturer's profesionalism and its impact to lecturer's performance]. Disertation. Universitas Brawijaya. Malang.
Sekaran, U. (2003). Research methods for business: A skill-building approach $\left(4^{\text {th }}\right.$ editions). John Wiley and Son Inc. USA.

Shore, L. M., \& Tetrick, L. E. (1991). A construct validity study of the survey of perceived organizational support. Journal of Applied Psychology, 76(5), 637-643.

Shore, L. M., \& Wayne, S. J. (1993). Commitment and employee behavior: Comparison of affective commitment and continuance commitment with perceived organizational support. Journal of Applied Psychology, 78(5), 774-780.

Tan, G., Kuo, C., \& GEH, E. Z. Y. (2010). Spirituality at work and organizational citizenship behavior: A replication study in Taiwan. Retrived from http:// ink.library.smu.edu.sg/lkcsb_research/2920/

Toker, B. 2011. Job satisfaction of academic staff: An empirical study on Turkey. Quality Assurance in Education, 19(2), 156-169.

Undang-Undang Nomor 14 Tahun 2005 tentang guru and dosen. Jakarta: Departemen Pendidikan Nasional Republik Indonesia. [Law No. 14 Year 2005 on teachers and lecturers. Jakarta: Ministry of National Education Republic of Indonesia].

Warsi, S., Fatima, N., \& Sahibzada, S. A. (2009). Study on relationship between organizational commitment and its determinants among private sector employees of Pakistan. International Review of Business Research Papers, 5(3), 399-410.

Wayne, S. J., Shore, L. M., \& Liden, R. C. (1997). Perceived organizational support and leader-member exchange: A social exchange perspective. Academy of Management Journal, 40(1), 82-111.

Weiner, B., Graham, S., \& Chandler, C. (1982). Pity, anger, and guilt: An attributional analysis. Personality and Social Psychology Bulletin, 8(2), 226-232.

Williams, L. J. \& Anderson, S. E. (1991). Job satisfaction and organizational commitment as predictors of organizational citizenship and in-role behavior. Journal of Management, 17(3), 601-617. 
Wexley, K. N., \& Yukl, G. A. (2005). Perilaku organisasi dan psikologi personalia. [Organizational behavior and personnel psychology]. PT Rineka Cipta. Jakarta.

Wulani, F. (2004). Analisis hubungan politik and dukungan organisasional dengan sikap kerja, kinerja and perilaku citizenship organisasional. [The analysis of the relationships between politics and organizational support and work attitudes, performance and organizational citizenship behavior]. KINERJA, 8(2), 111-132.

Yulianti, P. (2015). Pengaruh perceived organizational support terhadap organizational citizenship behaviors, organizational identification and affective commitment dengan creative organizational climate sebagai variabel moderator pada dosen PTN di Surabaya. [The Influence of perceived organizational support towards organizational citizenship behavior, organizational identification and affective commitment with creative organizational climate as moderator variable on public university lecturers in Surabaya]. Disertasi. Program Pasca Sarjana Universitas Airlangga. Surabaya.

Zeinabadi, H. (2010). Job satisfaction and organizational commitment as antecedents of organizational citizenship behavior (OCBS) of teachers". Procedia Social and Behavioral Sciences 5, 998-1003.

Notice: The Journal of Indonesian Economy and Business and its Board of Editors are not responsible for any errors or flaws found in this article. The authors take full responsibility for their work. 